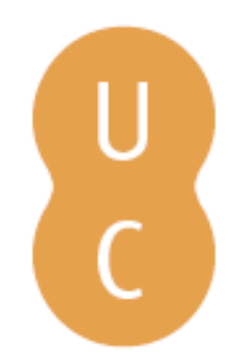

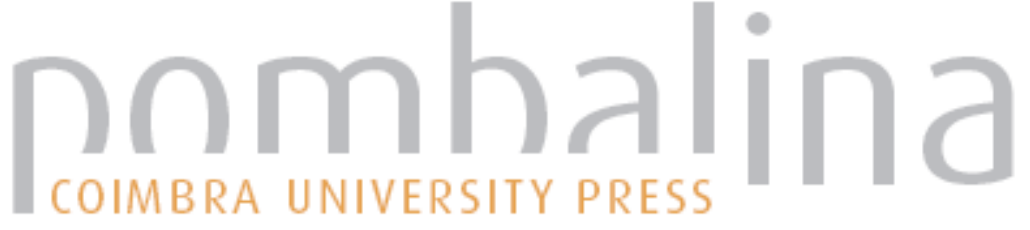

\section{Imaging in emergency radiology: clinical and forensic aspects}

Autor(es): $\quad$ Rodríguez-Calvo, M. S.; Baleato, S.; Muñoz, J. I.; Concheiro, L. Publicado por: Imprensa da Universidade de Coimbra; International Academy of Legal

URL

persistente:

URI:http://hdl.handle.net/10316.2/31822

DOI:

DOI:http://dx.doi.org/10.14195/978-989-26-0173-1_43

Accessed : $\quad$ 26-Apr-2023 09:55:15

A navegação consulta e descarregamento dos títulos inseridos nas Bibliotecas Digitais UC Digitalis, UC Pombalina e UC Impactum, pressupõem a aceitação plena e sem reservas dos Termos e Condições de Uso destas Bibliotecas Digitais, disponíveis em https://digitalis.uc.pt/pt-pt/termos.

Conforme exposto nos referidos Termos e Condições de Uso, o descarregamento de títulos de acesso restrito requer uma licença válida de autorização devendo o utilizador aceder ao(s) documento(s) a partir de um endereço de IP da instituição detentora da supramencionada licença.

Ao utilizador é apenas permitido o descarregamento para uso pessoal, pelo que o emprego do(s) título(s) descarregado(s) para outro fim, designadamente comercial, carece de autorização do respetivo autor ou editor da obra.

Na medida em que todas as obras da UC Digitalis se encontram protegidas pelo Código do Direito de Autor e Direitos Conexos e demais legislação aplicável, toda a cópia, parcial ou total, deste documento, nos casos em que é legalmente admitida, deverá conter ou fazer-se acompanhar por este aviso.

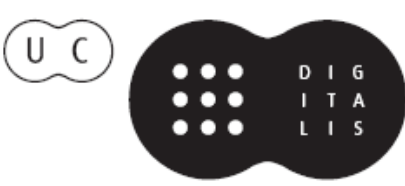




\section{Duarte Nuno Vieira Anthony Busuttil \\ Denis Cusack • Philip Beth}
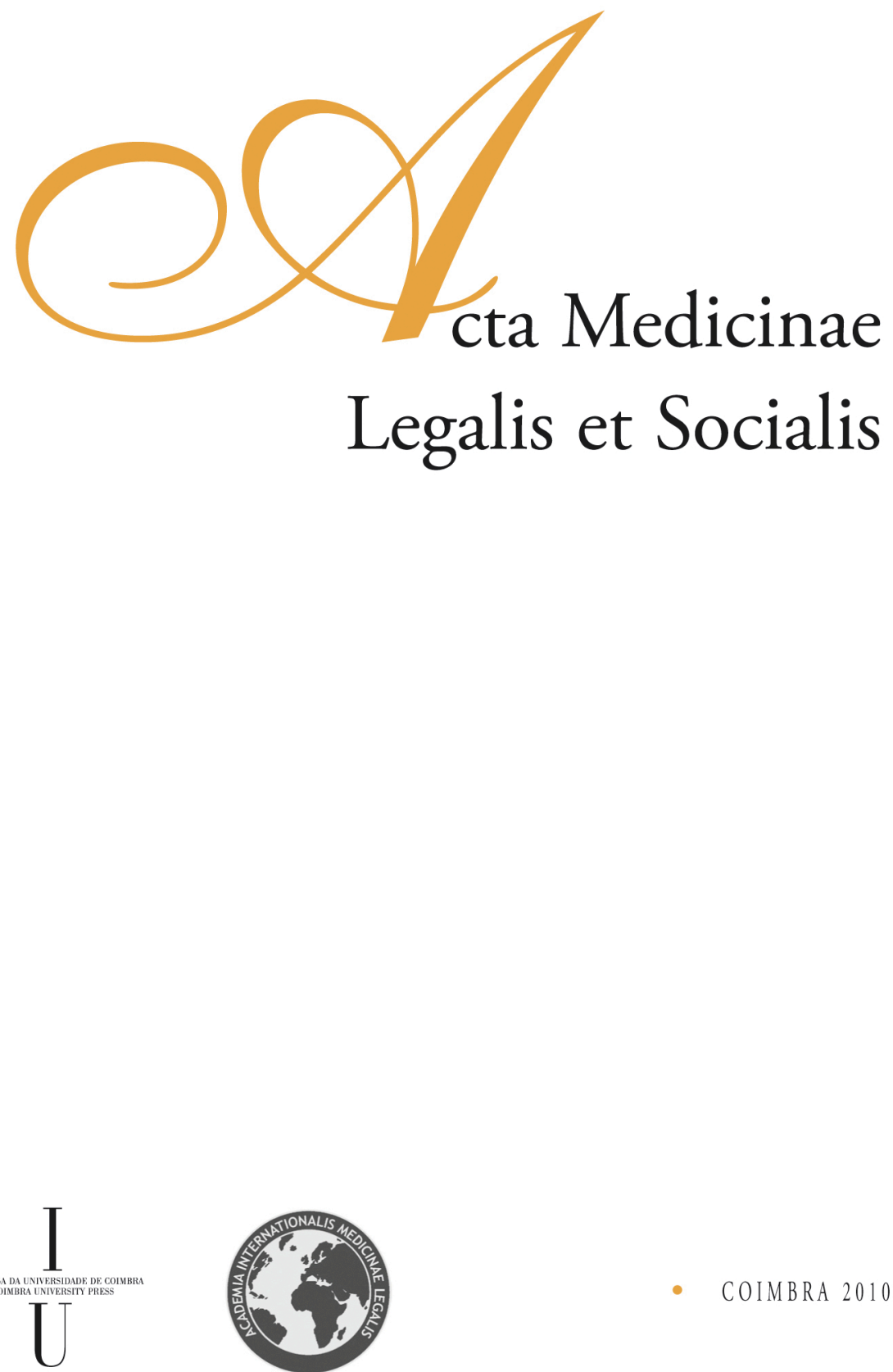
${ }^{1}$ Department of Pathology and Forensic Sciences, University of Santiago de Compostela, Spain

${ }^{2}$ Department of Radiology, Montecelo Hospital, Pontevedra, Spain

\title{
IMAGING IN EMERGENCY RADIOLOGY: CLINICAL AND FORENSIC ASPECTS
}

\begin{abstract}
Radiologists are frequently faced with different clinical situations that may have medico-legal implications. In these cases, Radiology can help document all findings and is, therefore, of great value when medical-legal issues are raised, both in the clinical field and in post-mortem examination. The main objectives of forensic medicine are to document, analyze, and elucidate scientific medical findings in both living and deceased persons in a comprehensible way for courtroom presentation. This work presents several cases in which importance of radiological examination is self-evident. These include: foreign material into the body (body packer, intraabdominal metal splinter, aspiration of a foreign body), professional malpractice (inadequate placement of a catheter, intraabdominal migration of an intrauterine device) or intentional injuries (cranial fracture). Emphasis has been placed on the contribution of the new imaging techniques (Computed tomography, Magnetic resonance) which constitute the basis of the so-called virtopsy.
\end{abstract}

\section{Introduction}

The radiological examination can be a very useful ancillary method for the expert in both clinical forensic medicine and forensic pathology. In the clinical forensic setting, imaging can be the only or even the best evidence of the problem. Of equal importance is the anticipation of what injuries to look for in the autopsy, or to obtain an objective clue that could be related to the cause of death when the patient has undergone medical o surgical treatment prior to death. The new imaging techniques (CT and MRI) increase considerably the efficacy of radiological applications in forensic medicine [1,2].

This work presents several clinical cases in which the radiological examination performed (CT) could be fundamental for the courtroom presentation of the evidence in both fields.

\section{Cases Report}

\section{Foreign material inside the body}

A. Body packer: A 21-year-old man, known to have swallowed a number of packages of cocaine in the previous 48 hours, presented to the Emergency Department of the 
Hospital complaining of abdominal pain and vomiting. A plain abdominal radiograph revealed a number of packages within the abdomen $(4 \times 1 \mathrm{~cm})$, and evidence of bowel obstruction, that were confirmed by CT (Figure 1). An emergency laparotomy was performed to remove the cocaine packets. He was discharged on the tenth day without complications.

Unenhanced MDCT thus not only essentially contributes to the clinical emergency management of cocaine dealers, but also helps resolving legal questions by furnishing the immediate proof of ingested drugs, if any. The plain abdominal radiography is imperfect as a screening method.

\section{B. Foreign objects accidentally introduced in the body:}

B.1. Intra-abdominal metal splinter: A 45-year-old British man was admitted to the Emergency Department with abdominal contracture and strong pain on palpation. He refers that an unknown object entered his abdomen while working with a lawnmower. Plain radiology and CT confirm a foreign metallic object in the abdominal cavity (Figure 2). Perforation of the small intestine is confirmed by laparotomy and intestinal resection and reconstruction with $\mathrm{T}-\mathrm{T}$ anastomoses was performed. The evolution was good and the patient discharged eight days later.

B.2. Aspiration of a foreign body: A 59-year-old woman visits the Emergency Department with chronic cough and, in the last $24 \mathrm{~h}$, expectoration and fever. Chest radiography and thoracic CT showed an opaque segment corresponding to the left superior pulmonary lobe. Also, a hyperdense ( - bone) linear image $( \pm 2.5 \mathrm{~cm})$ nearby the left bronchus was incidentally seen (Figure 3). A diagnosis of atelectasis of the left superior pulmonary lobe with stenosis of the corresponding bronchus was made.

\section{Foreign objects in the context of professional malpractice:}

C.1. Intra-abdominal migration of an intrauterine device (IUD): A 28-year-old Brazilian woman visits the emergency department with headache, fever, chills, nausea and vomiting. She had an IUD inserted seven years ago, with no further revision. She refers abundant vaginal bleeding that resulted in anemia. An abdominal CT shows a large irregular fluid-density lesion within the right lobe of the liver which was confirmed to be a pyogenic hepatic abscess. Also, an IUD was seen outside the uterine cavity (Figure 4). Patient underwent abscess drainage and antibiotic therapy.

C.2. Inadequate placement of a catheter: A 52 year-old man with a history of an epidermoid carcinoma of larynx was admitted to hospital with acute respiratory problems (shortness of breath) caused by an obstructive mass on the epiglottis. After the patient was stabilized, a total laryngectomy was carried out. Because of complications after surgery, medication and nutrition through a nasogastric tube were indicated. In the follow up a nasogastric tube in vena cava was revealed in radiology as an incidental finding (Figure 5).

C.3. Gauze left in abdomen: A 38 year old woman was admitted to hospital with persistent abdominal/pelvic pain after previous surgery. An abdominal/pelvic CT shows the image of a foreign body on the left side of pelvic cavity (Figure 6). 
As we can see, CT has the advantage of exactly locating the foreign object and demonstrating their topographic neighbourhood, thus facilitating its extraction. Also, postmortem CT can help document the correct/incorrect position of tubes/catheters etc, prior to any autopsy and is therefore, of great value when medical-legal issues are raised [3].

\section{Intentional injuries:}

Cranial fractures: A 90-year-old woman was admitted in the Emergency Department with an open traumatic brain injury. The patient presented multiples incised wounds in the parieto-temporal part of skull and a depressed fracture with loss of brain parenchyma. Cranial CT showed pneumoencephalus, skull fracture (Figure 7) and a parieto-temporal brain contusion. After seven days in the intensive care unit the patient died.

Fracture distribution can be easily visualized and examined in a non destructive fashion. Also, it becomes possible to answer questions regarding the dynamics of patterned injuries and to evaluate their linkability to suspected injury-causing instruments even after the body has been buried. These methods can be used for forensic purposes in both living and deceased persons [3].

\section{Conclusions}

The application of imaging methods for non-invasive documentation and analysis of relevant forensic findings in living and dead persons has lagged behind the enormous technical development of imaging methods [4]. Imaging techniques are nowadays excellent tools for forensic medicine. They allow permanent preservation of a document of proof, whether the victim is dead and undergoing post-mortem decay or surviving and losing evidence due to healing. This method of documenting forensic findings is investigator independent, objective and non-invasive and will lead to qualitative improvements in forensic clinical and pathology investigations.

\section{References}

1. THALI MJ, YEN K, SCHWEITZER W, VOCK P, BOESCH C, OZDOBA C, SCHROTH G, ITH M, SONNENSCHEIN M, DOERNHOFER T, SCHEURER E, PLATTNER T, DIRNHOFER R. Virtopsy, a new imaging horizon in forensic pathology: virtual autopsy by postmortem multisclice computed tomography (MSCT) and magnetic resonance imaging (MRI) - a feasibility study. J Forensic Sci 48:386-403, 2003.

2. BOLLIGER SA, THALI MJ, ROSS S, BUCK U, NAETHER S, VOCK P. Virtual autopsy using imaging: bridging radiologic and forensic sciences. A review of the Virtopsy and similar projects. Eur. Radiol. 18(2):273-82, 2008.

3. DIRNHOFER R, JACKOWSKI C, VOCK P, POTTER K, THALI MJ. VIRTOPSY: minimally invasive, imaging-guided virtual autopsy. Radiographics 26:1305-1333, 2006.

4. THALI MJ, JACKOWSKI C, OESTERHELWEG L, ROSS SG, DIRNHOFER R. VIRTOPSY - The Swiss virtual autopsy approach. Legal Medicine 9:100-4, 2007. 


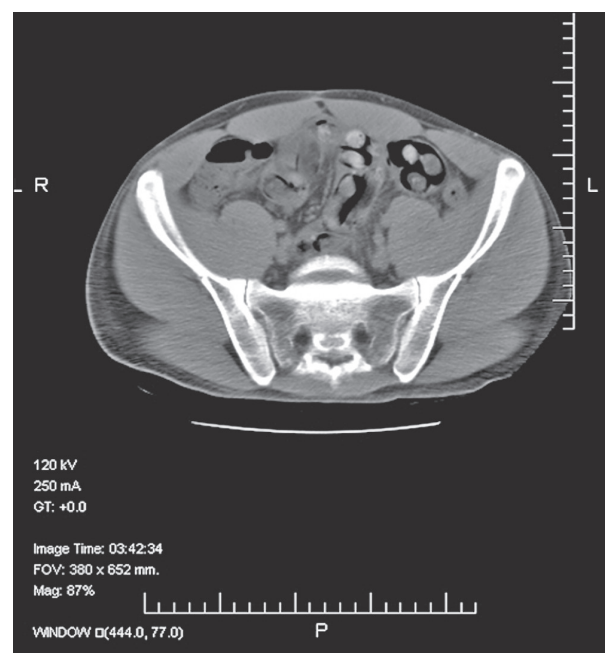

Figure 1 - CT image of the abdomen

demonstrates multiple drug packages in the colon.

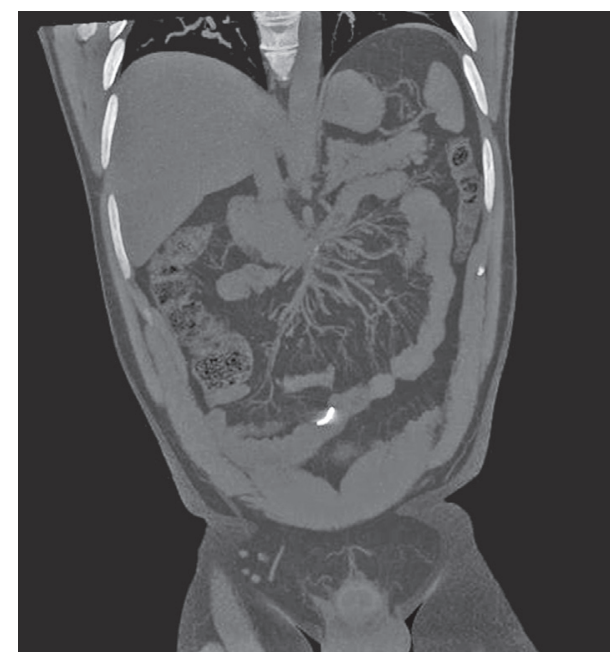

Figure 2 - Coronal MPVR-MIP confirms an intraluminal foreign body.

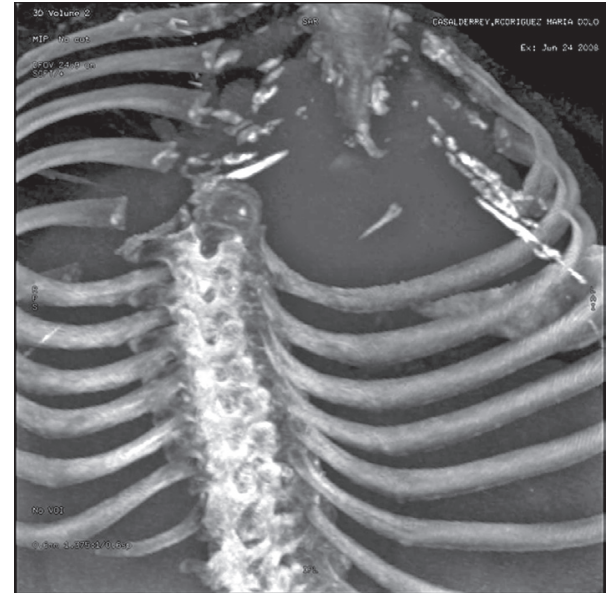

Figure 3 - MPVR identifies a high density lineal image compatible with a chicken bone.

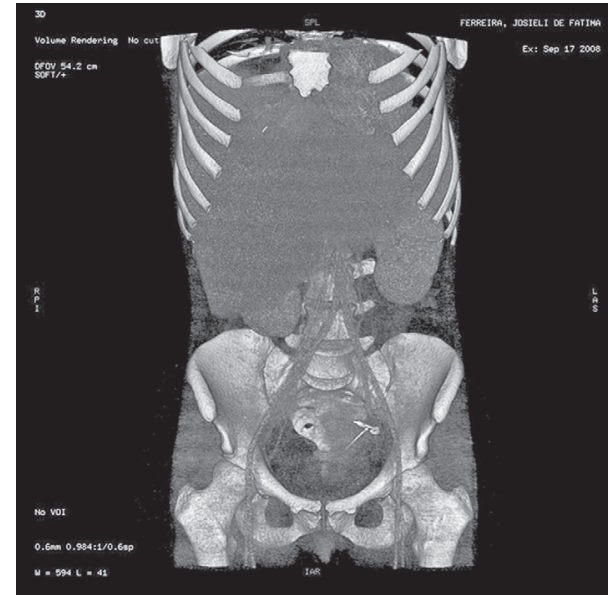

Figure 4 - MPVR clearly identifies the IUD outside the uterine cavity. 


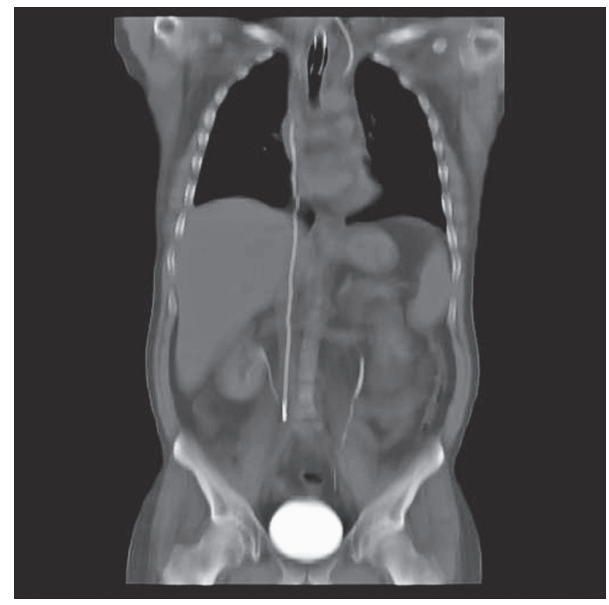

Figure 5 - MPVR shows the nasogastric tube following the path of vena cava. Incidentally, urethers can be visualized because of renal elimination of contrast.

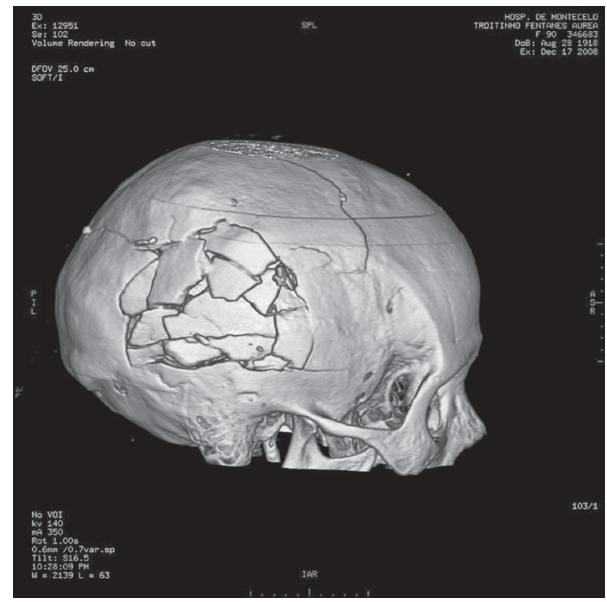

Figure 7 - Injury caused by blows to the head. Oblique lateral 3D VR CT image shows a typical local impression and ring fracture of the parietal skull due to blows with a blunt object.

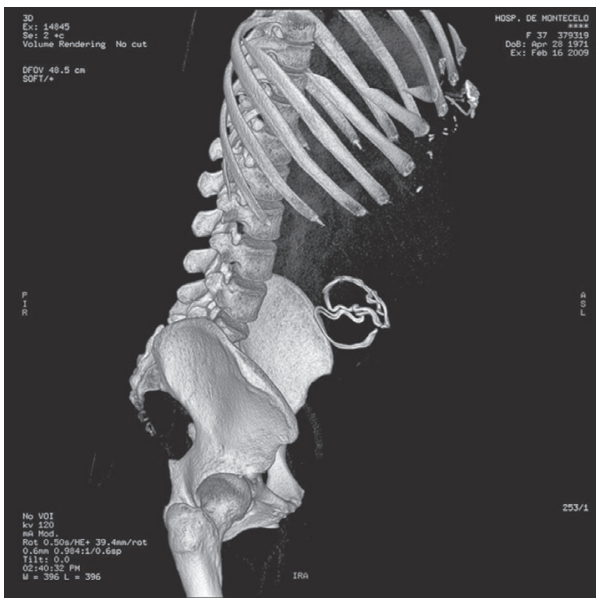

Figure 6-MPVR showing the image of the retained gauze in abdominal cavity. 